\title{
Model of Risk Assessment (MORA) concept for the investment part of urban regeneration projects
}

\author{
Magdalena Apollo, Elżbieta Urbańska-Galewska \\ Gdansk University of Technology, Narutowicza 11/12 Str., 80-233 Gdansk, Poland
}

\begin{abstract}
The main goal of this paper is presentation of the model concept (MORA) that will be used to control level of risk and manage technical risk in investment projects in the area of urban regeneration risk management.

The publication was preceded by initial research and consultation with subjects involved in the process of urban regeneration of Gdansk district Letnica. It revealed numerous problems with coordination of the project, which resulted in increasing cost and longer time of project completion. Previous research also indicates that complex and social nature of urban regeneration determines the occurrence of number of risks that are not typical for regular investment projects. In relation to the above, the target mathematical model, being final outcome of the research, aims to measure percentage increase of the investment cost in relation to initial assumptions of urban regeneration projects. Construction of the proposed model is assumed to be based on qualitative and quantitative.
\end{abstract}

Keywords: urban regeneration; MORA; risk management; complex investment projects.

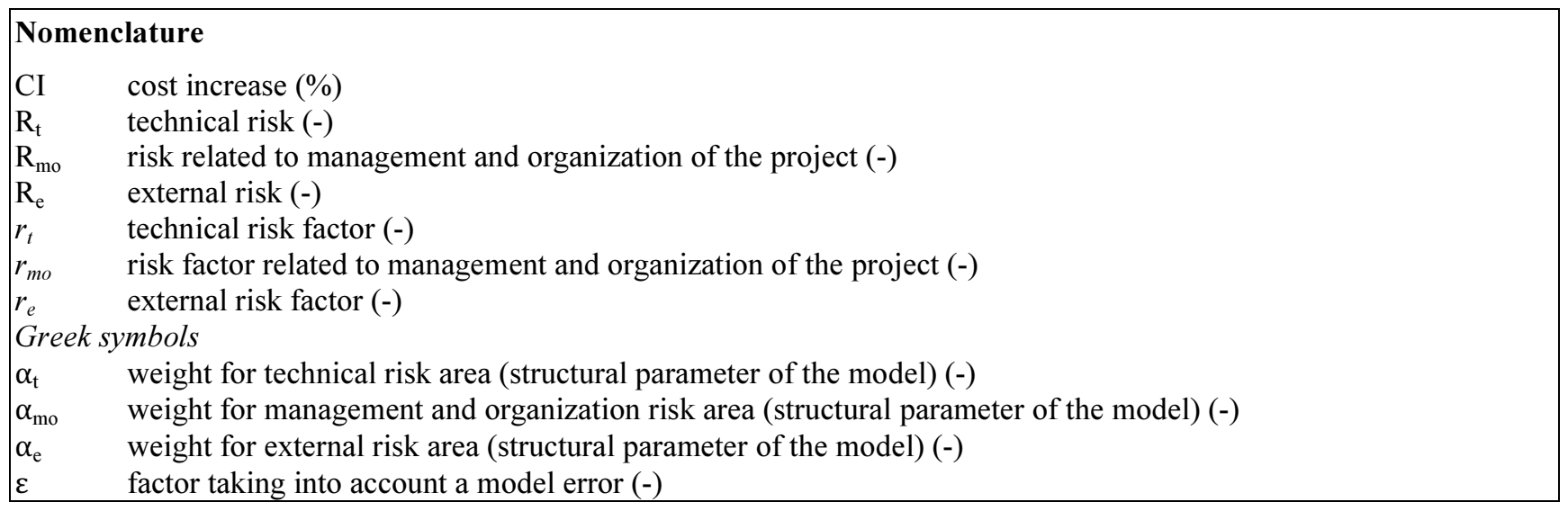

\section{Introduction}

Investment activity in the construction industry comprises the construction of new buildings, as well as extension, modernization or adaptation of existing buildings in accordance with changing needs of their users. Independently from the form it takes, construction investment involves undertaking and completing many complex concept, legal, design and construction tasks [1]. The purposefulness, profitability and feasibility of the planned investment are verified at the concept stage.

The basics of assessment of investment projects are: financial efficiency, time of completion and involved risk that is analyzed in many aspects. Due to key importance to the success of the whole construction process and the specifics of research done, special focus is on the third listed category - risk, mainly technical in nature, and the factors that cause it.

Identification and verification of risk is necessary as it may bring financial savings or losses, which is extremely important for making investment decisions. Important features of risk is its dynamic and economic characteristic, depending

Corresponding author: Magdalena Apollo. E-mail address: magdalena.apollo@wilis.pg.gda.pl

http://dx.doi.org/10.3846/enviro.2014.105

(C) 2014 The Authors. Published by VGTU Press. This is an open-access article distributed under the terms of the Creative Commons Attribution License, which permits unrestricted use, distribution, and reproduction in any medium, provided the original author and source are credited. 
on the value of risk factors defined as measurable amounts that can impact occurrence of specific kind of risk. Risk factors that impact the level of profitability of the investment should therefore be identified and described, both qualitatively and quantitatively.

Taking into account the above, urban regeneration should be considered as a specific type of investment project. The term 'urban regeneration' describes numerous undertakings related to a group of buildings, which due to economic changes have partially lost their initial function. It is a set of actions in the construction, planning, economy and social policy area, aiming at recovery, improvement of functionality, aesthetics, comfort and quality of life of the inhabitants of the area in scope. Because of that ventures included in urban regeneration projects have to include investment and non-investment tasks (Fig. 1).

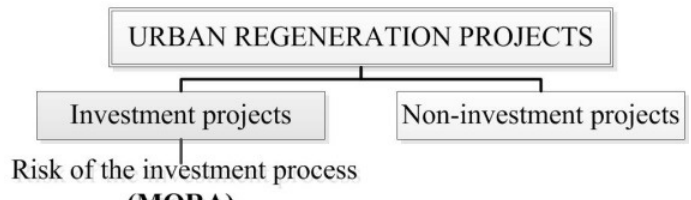

(MORA)

Fig. 1. Types of projects under urban regeneration [self-sourced]

Urban regeneration is not an ordinary investment project. In general, construction works are associated with erection, modernization and tearing down buildings eliminating participation of residents. In the analyzed area however, an extremely important is the social aspect considered as an active participation of residents in decision-making process as well as their presence on a future building site. Moreover, previous research indicates that complex and social nature of urban regeneration determines the occurrence of number of risks that are not typical for regular investment projects. Therefore, it is advisable to construct Model of Risk Assessment (MORA) that will be used to control level of risk and manage technical risk in investment projects in the area of risk management of urban regeneration (Fig. 2).

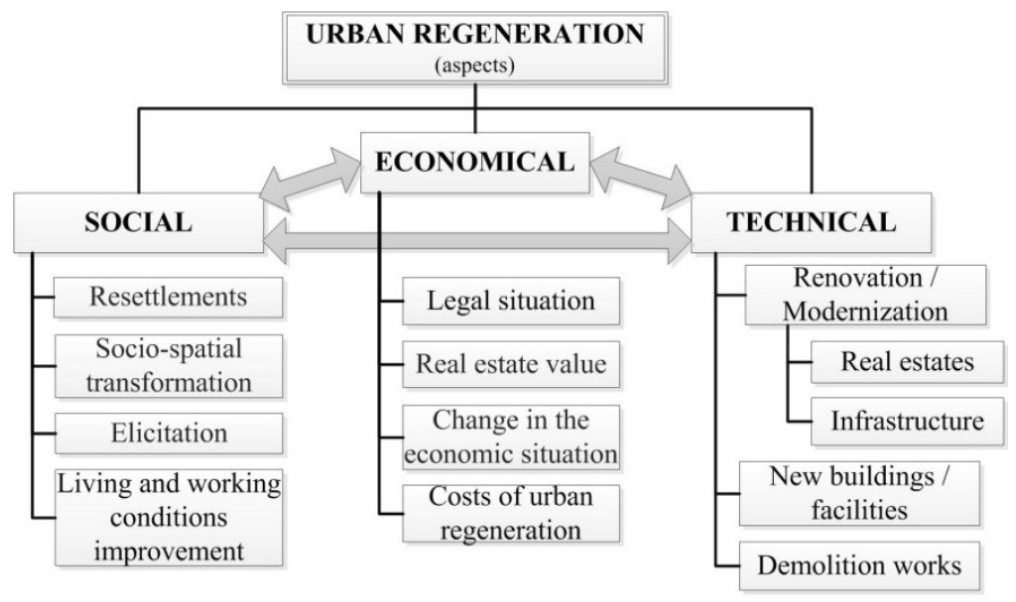

Fig. 2. Social, economic and technical aspects of urban regeneration projects [self-sourced]

\section{Risk of the investment process}

The subject of urban regeneration has not been considered before in the technical context of risk management, also systemic processes addressing this area are lacking. Due to the social as well as cultural impact of the project, the decision to make the investment is conditioned, we could say, beyond the economic considerations, and certainly does not take into account the potential risks of a technical nature. The initiation of an urban regeneration project is subject to legal complications due to lack of established laws and regulations in Poland, and it is also dependent on securing the financing. And here again social and environmental considerations and partnership agreement determine successful project completion. The technical aspects are addressed in documents such as: feasibility study, extract of the technical documentation and building permit [2]. None of the above mentioned documents, however, addresses the risk identification and analysis, which as demonstrated in the urban regeneration of Letnica - district of Gdansk project, can drastically affect project budget.

In practice, the only document taking elements of risk management into account in urban regeneration projects is the feasibility study. For every infrastructural project a set of possible scenarios is prepared, assessed and compared using agreed criteria. It is worth noticing, that criteria considered do not relate to risk level, instead they relate to the possibility of achieving set goals in the area of improving social, economic and infrastructural situation of the neighborhood, city and the entire region. Such analysis serves only to choose investment scenario, and does not take into account technical risk related to particular tasks. What is more, proper risk analysis is only a small part of a wider economic analysis in the chapter related 
to financial-economic feasibility and is narrowed down to descriptive and qualitative form, which is not measurable and is subjective. This way the important technical aspect of risk management resulting from the cooperation of numerous executive entities in the design and implementation phase of investment is missing. There is lack of tools as well as research directed to quantitative, objective description and measurement of the technical risk level in the specific urban regeneration project.

Such a complex undertaking as urban regeneration determines the occurrence of a number of risks that are not typical for regular investment projects. That is, inter alia, because local community living in revitalized areas (especially municipal) contributes to a number of potential obstacles potentially affecting effectiveness of investment process. Urban regeneration furthermore determines the occurrence of extremely many sources of risk, which in general may include [3-4]:

- large scope and cost of project

- uniqueness and innovativeness

- rushed planning and implementation

- lack of required skills on the project management team as well as project team involved in execution

- excessive bureaucracy contributing to conflicts regarding project coordination

- unfavourable contracts on the line investor-contractor

- incorrect identification of the technical conditions.

The accumulation of many complex factors and their mutual correlations become the cause of many problems of urban regeneration, which often prevents a successful delivery of the project. The factors include, but are not limited to [3-4]:

- lack of good examples of successfully executed domestic, complex urban regeneration projects of urban areas (that can serve as templates)

- lack of clearly defined funding process

- lack of appropriate statutory and therefore legal regulations

- progressing decapitalization of estates - mainly residential, often leading to their physical demolition.

The paper was preceded by initial research and consultation with subjects involved in the process of urban regeneration of Gdansk district Letnica [5-6-7-8]. It revealed numerous problems with coordination of the project, which resulted in increasing cost and longer time of project completion. It is worth noticing that majority of problems was caused by overlapping schedules of buildings refurbishment works and street modernization works, which caused issues with the works themselves and with moving tenants. During the research the following types of main technical risk factors have been identified [9]:

- conducting works in unusual conditions (major degradation of inhabited buildings and infrastructure, making it difficult to make full inventory of the building; difficulties in defining scope)

- works on object of significant historic value (listed objects): the necessity to obtain proper permits and to use special technology and building materials

- simultaneous renovation of the building and infrastructure, as well as implementation of complimentary investments in direct vicinity of the area undergoing renovation: manoeuvring of heavy equipment in limited space - possibility of damaging nearby objects, limited storage space for materials and equipment

- design errors: not planned for increase of weight caused by changes in construction (usually from wooden to reinforced concrete) and changes in functional plan, insufficient of erroneous assessment of ground and water conditions causing wrong selection of strengthening technology for foundations not taking into account the real interaction between the foundations and ground, incorrect assessment of construction settlement, wrong static diagram

- significant humidity in renovated buildings (gaps in vertical and horizontal insulation of foundations and basement walls, humid rooms on wooden ceilings lacking proper insulation) not sufficient time for building seasoning (potential reoccurrence of biological corrosion)

- lack of current technical documentation regarding underground infrastructure.

The consequence of accumulation of numerous risk factors in discussed project were numerous technical problems, among others:

- scratches of walls in the repaired buildings, being the effect of the hardening of subsequent layers of pavements on roads in the building proximity,

- uneven settlement and deformation of the renovated buildings caused by the process of pressing piles into the ground being prepared for new objects in the buildings proximity; the technology had to be changed into a screwed piles technology (commercial tasks realised by GTBS Sp.z o.o. and TBS "Motława" Sp.z o.o.) [6].

The source of majority of discovered problems was lack of in-depth analysis of risk sources and factors. However, some of reasons of delays on the construction site and cost increases, are caused by unforeseeable mistakes made during planning phase. The others are caused by 'human factor' (mistakes, negligence, lack of competence, old and unreliable information being passed on).

Some of identified difficulties in management and organization are directly caused by the already mentioned lack of proper legal regulation. Urban redevelopment in Poland lack fundamentals, including even the definition of the term, which is caused by a gap in the legal system. Since 1992 urban regeneration bill is being created. In 1998 the Society Forum of Urban Regeneration ('Stowarzyszenie Forum Rewitalizacji') joined the effort; it supports systemic ways of urban regeneration stimulation. Despite putting the works on the bill project on hold (2002), organizations involved in urban regeneration process still want for urban regeneration bill to be part of country's spatial planning. The main argument in 
favor is social impact of such projects, as well as developed plans for urban regeneration investments in several places in Poland. If urban regeneration bill existed, it would solve many of current problems of urban regeneration, among others those related to limiting private ownership rights for public interest.

To sum up, theoretical aspects of urban regeneration are widely described in international subject literature, still there is lack of in depth research regarding Polish situation, especially referring to technical aspects of urban regeneration. Among numerous literature we can mention works of K. Skalski (founder of the society Urban regeneration Forum), P. Lorens, T. Parteka, Z. Ziobrowski, and among international works such authors as I. Colquhoun (with the key work "Urban Urban regeneration. An International Perspective") [10]. Special attention should be directed to the series „Rewitalizacja miast polskich" ("Urban regeneration of Polish Cities"), initiated by the Institute of Cities Development in 2009 [11].

Due to existing need of extensive research in management of complex investment enterprises, identification and classification of technical risks and risk factors as well as construction of author's Model of Risk Assessment (MORA) may bring significant results, especially in the area or risk management in urban regeneration projects.

\section{Model of Risk Assessment (MORA) concept}

Due to above mentioned risks involved in the process of urban regeneration, it is advisable to develop the problem of identification and classification of risk areas as well as risk factors in the technical aspect of design and implementation phase of building projects (the authors pay special attention to industrial areas within the city). The main goal of the conducted research is to construct a Model of Risk Assessment (MORA) which will be achieved through completion of several partial stages, including:

- building a database of risk for investment projects realized as part of urban regeneration projects; identification and categorization of risk according to their sources

- creation of a ranking of risks impacting the project

- construction and verification of mathematical model using simulation methods.

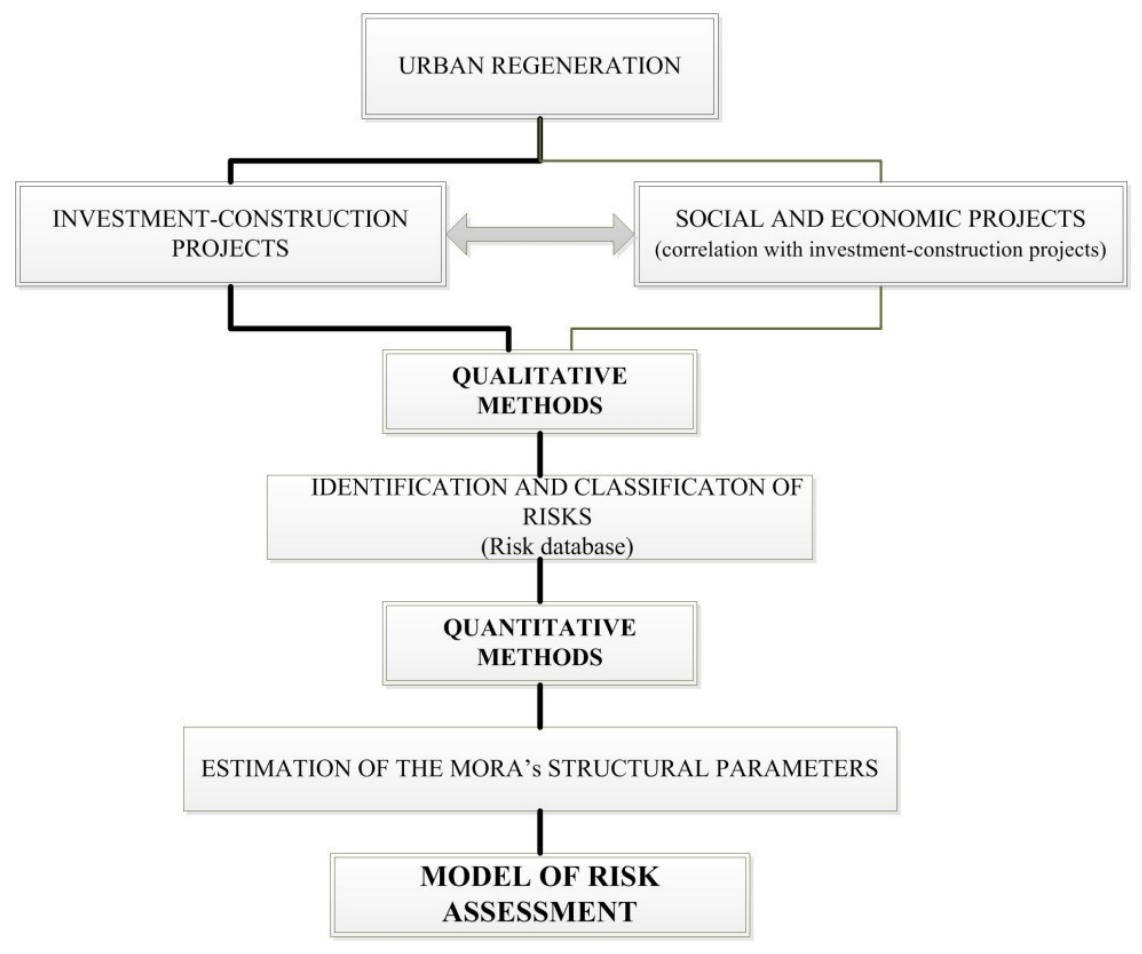

Fig. 3. General scheme of research methodology [self-sourced]

The first stage of the research is building a database of risk for investment projects realized as part of urban regeneration, based on analysis of bottlenecks. The method aims to identify potential risks that if realized can result in the most damaging loss from the investment budget standpoint. Due to the complex and social nature of urban regeneration, the analysis plans to verify correlation of technical aspects with social and economic aspects of urban regeneration.

The next step is creation of a risks' ranking impacting the project. Identification of correlations between specific risks, but also identification of those risks that significantly impact general level of investment risk in the changing scope of urban regeneration projects is going to be carried out on the basis of DEMATEL method (Decision Making Trial and Evaluation Laboratory). The above mentioned method allows identification of delays causes and their impact on the entire investment risk by position and relation indicators. For the risks that significantly impact urban regeneration investment costs there is a plan to make the analysis more specific. 
The outcome of the research will be to determine weights of particular types of risks also known as structural parameters for the MORA model and construction of a mathematical model Cost Increase (CI). Verification of the significance of model structural parameters using simulation methods will take into account time and cost criteria. General scheme of the research methodology is presented on Figure 3.

According to the presented concept, the target mathematical model will measure percentage increase of the investment costs in relation to initial assumptions of urban regeneration projects. Econometric form of the model is presented wthin "Equation (1)". It is assumed that three main areas of investment process risk factors total to percentage of cost increase, based on that one can define:

- technical risk $\left(R_{t}\right)$ : all threats linked to quality and efficiency goals that are affected by the technology used in the project

- risk related to management and organization $\left(R_{m o}\right)::$ mainly coordination problems, but also lack of specialized resources and personnel monitoring process of urban regeneration as well as contracts difficulties

- external risk $\left(R_{e}\right)$ : risk caused by third parties, therefore possibility of affecting and mitigating this area is limited.

$$
C I=\alpha_{t} R_{t}+\alpha_{m o} R_{m o}+\alpha_{e} R_{e}+\varepsilon \quad(\%)
$$

Every analyzed risk aspect contains smaller elements called risk factors, therefore extended version of "Equation (1)" is presented in "Equation (2)". Due to used econometric form, the model error $(\varepsilon)$ assuming occurrence of factors not defined in risk identification process is analyzed separately.

$$
C I=\alpha_{t} \sum_{i=1}^{n} r_{t i}+\alpha_{m o} \sum_{i=1}^{m} r_{m o i}+\alpha_{e} \sum_{i=1}^{k} r_{e i}+\varepsilon \quad(\%)
$$

Verification of accepted level of investment risk in urban regeneration should be done in accordance with risk management procedures and is presented on Figure 4. In the first phase it assumes identification of risk specific for the project, based on prepared control list. Identified risk factors are put into the model, as non-zero values, and undergo quantitative analysis. Depending on what accepted risk level is agreed (potential budget reserve; level of acceptable risk as a percentage of project value) in the next stage a decision is made regarding accepting or rejecting risk level, which results in taking actions aimed at minimizing risk level (control measures). Independently from calculated risk level, risk management requires constant analysis of the situation in aspect of potential risk factors occurrence (monitoring and control).

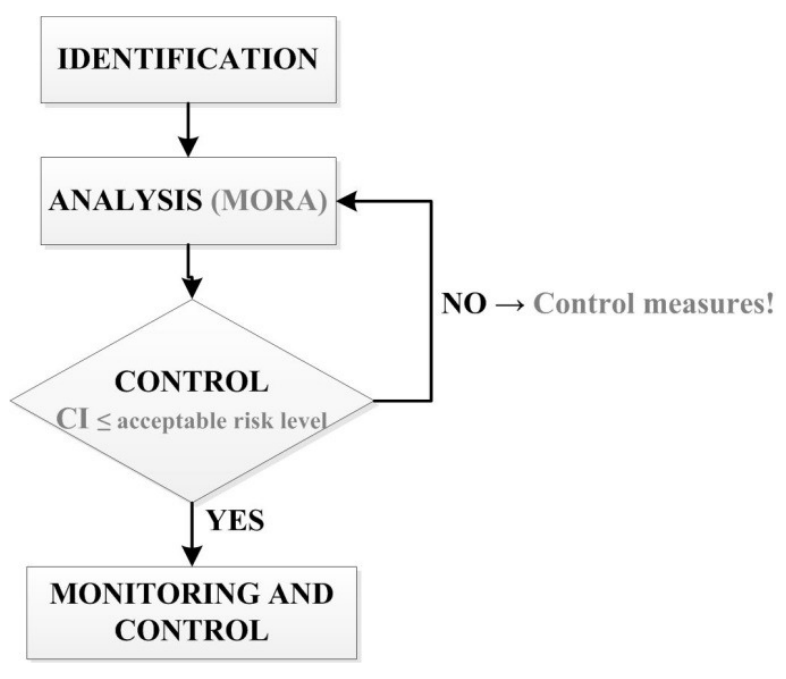

Fig. 4. Algorithm of verification of accepted investment risk level in accordance with the procedure of risk management [self-sourced]

\section{Initial assessment of model's structural parameters}

The research is still in progress, nevertheless the main risk areas both on investor and contractor side have been identified. In order to obtain information, apart from the bottlenecks analysis, the following techniques of identifying risks were used [9]:

- analysis and assessment of documentation related to preparing and implementing selected regeneration projects in Gdansk

- direct observation including consultations with experts involved in the projects

- analysis of project assumptions and organization structure of selected ventures (communication breaks, bottlenecks, interdependencies)

- analysis of available control lists, registers, literature

- available statistics regarding risk factors in complex investment enterprises, as well as damages and breakdowns of buildings (looking for analogies with constructions from the turn of $19^{\text {th }}$ and $20^{\text {th }}$ century) 
Detailed list of factors affecting investment risk in urban regeneration was prepared (control list) basing on results of research described above (taking into account only those factors which negatively affect the project). The list includes risk factors related to particular phases of investment process and inherently connected to the process. What is more, the same kinds of risk occur both on the investor and contractor side, however their intensity and impact depends on the relation (contract) between those parties. All identified factors have been divided into three groups: technical risk factors, risk factors related to management and organization of the project as well as external risk factors.

Assuming the most unfavourable circumstances of probability being 1.0 and impact of the risk factor being 1.0 risk values, also called a range (risk = probability x impact), for every factor were established. Summarised value of risk for every assembled factor allowed, in the next stage of research, standardization of variables in the range $0-1$, which in turn allowed defining a share of every analysed area in overall urban regeneration investment risk.

The level of details of so far conducted analysis, verified with group of experts, allows to assume that vast majority of potential negative factors has been identified (so called threats or risk factors). It is therefore possible to estimate the share of each of those areas in the overall investment risk of urban regeneration project, which was achieved by creating so called "reference model". The model is based on five-step scale of probability and impact of occurrence of a risk factor. Level one is defined as a rare occurrence (probability below 1\%) at the same time the impact is deemed to be insignificant. Level five defines an almost certain occurrence (border value of probability equal 1.0) with catastrophic impact (significant extension of the timeline of the project, significant increase of costs).

Research done to date and analysis described above allowed defining model's structural parameters for each risk area presented in "Equation (3)". This way one managed to build the initial form of the model (before consulting group of experts) where instead of weights $\left(\alpha_{i}\right)$, the shares of each risk area in the overall investment risk were introduced.

$$
C I=0,4 R_{t}+0,26 R_{m o}+0,32 R_{e}+\varepsilon(-) .
$$

\section{Conclusions}

To sum up, identification, analysis and quantifying of risk factors is a fundamental element of the strategy to prevent problems, which may result in social and economic outcomes. Both of them are important, because generated social problems may develop and cause economic costs, for example reluctance of people to live in the new, regenerated buildings. Those problems also have important impact in changing the way the construction project participants think about potential risk factors during preparation, implementation and operation phases. Planned research aims at building knowledge base regarding important factors of technical risk. What is more, as the Faculty of Civil and Environmental Engineering of Gdansk University of Technology cooperates with Gdansk Municipal Real Estate Management (based at Partyzantów 74 in Gdansk), results of this research can contribute to application of MORA in one of the regenerated districts in Gdansk and what is more, may lead to better management of investment projects being part of urban regeneration

Presented research confirms complexity and problematic nature of complicated investment ventures, as well as allows creation of general range of risk in respect of significance of specific, key areas and their share in the overall investment risk. The research draws attention to the distribution of power between parties involved in urban regeneration, but data obtained is also practically usable. The solution presented is a base for planned quantitative-qualitative research in this area. The significance of further research is caused by the complexity of urban regeneration venture. The implication of this complexity is the need for holistic approach to the subject, including analysis of relations between different risk areas and factors.

\section{References}

[1] Kowalczyk, Z.; Zabielski, J. 2010. Kosztorysowanie i normowanie w budownictwie. Wydawnictwa Szkolne i Pedagogiczne Spółka Akcyjna. Warsaw.

[2] Wniosek o dofinansowanie projektu w ramach Regionalnego Programu Operacyjnego dla Województwa Pomorskiego na lata 2007-2013.

[3] Lorens, P.; Martyniuk-Pęczek, J. 2009. Wybrane zagadnienia rewitalizacji miast. Wydawnictwo Urbanista. Gdańsk.

[4] Lorens, P. 2010. Rewitalizacja miast. Planowanie i realizacja. Wydział Architektury Politechniki Gdańskiej.

[5] Apollo, M.; Kristowski, A. 2012. Logistyka realizacji robót budowlanych podczas rewitalizacji dzielnicy Gdańsk-Letnica, Logistyka 3/2012: 23-27. ISSN 1231-5478.

[6] Urbańska-Galewska, E; Apollo, M. 2012. Successfull urban regeneration project Gdansk-Letnica district case study, Civil and Environmental Engineering Reports 9: 133-142.

[7] Apollo, M.; Grzyl, B. 2013 Problemy koordynacji realizacji robót budowlanych na przykładzie rewitalizacji dzielnicy Gdańsk-Letnica, Inżynieria Morska i Geotechnika 5: 345-348.

[8] Apollo, M.; Urbańska-Galewska, E.; Wiśniewski, R. 2014. Aspekty społeczne, ekonomiczne i techniczne rewitalizacji na przykładzie dzielnicy Gdańsk-Letnica, in Kwartalnik Instytutu Rozwoju Miast „Problemy rozwoju miast”. Krakow (during the publication process).

[9] Apollo, M.; Brzezicka, J. 2014. Sources of investment risk in urban regeneration projects, in Czasopismo Techniczne. Krakow (during the review).

[10] Colquhoun, I. 1995. Urban regeneration. An International Perspective. London

[11] Janas, K.; Jarczewski, W.; Wańkowicz, W. 2010. Tom 10 cyklu Rewitalizacja Miast Polskich. Model rewitalizacji miast. Krakow. 